\title{
RESENHA DE "ESCOLA PARTIDA: ÉTICA E POLÍTICA EM SALA DE AULA”, DE RONAI ROCHA
}

\author{
Vítor Hugo dos Reis Costa ${ }^{1}$
}

"Ex nihilo nihil fit" é uma máxima da metafísica e da teologia medievais que, digamos, tinha como finalidade ajudar na organização do inventário de uma herança cultural cujas bases não eram compatíveis com aquelas do pensamento cristão no qual o universo é Criação de um Criador. A ideia de que "do nada, nada vem" pode ser talvez identificada como a ideia central do novo livro do professor Ronai Rocha, da Universidade Federal de Santa Maria, intitulado Escola partida: ética e política na sala de aula.

Se me fosse dado o direito de agenciar interpretativamente a obra do professor Ronai, eu ousaria dizer que o livro é o terceiro de uma trilogia que começaria com Sentimentos de outono, de 1997 e Quando ninguém educa, de 2016. E se o primeiro já parece distante de nós desde as brumas que deveriam separar o novo milênio do velho ao versar sobre questões da instituição universitária que foram superadas, esquecidas ou voluntariamente escamoteadas, o irmão-do-meio - que versa sobre o "freirismo cultural" eu tive oportunidade de ler e apresentar em eventos acadêmicos com o intuito de dar visibilidade para a obra e fazê-la circular do modo que merece. E se em 1997 o professor Ronai já denunciava algumas contradições da universidade brasileira, suas considerações sobre os extravios da prática pedagógica se tornariam, 20 anos depois, o tema de Quando ninguém educa e Escola partida, este último dedicado ao famigerado movimento "escola sem partido".

O que aconteceu conosco para que o passado permaneça tão atual?

Escola partida é uma tentativa de resposta para essa pergunta no que concerne aos modos pelos quais nós, docentes, compreendemos nossa própria prática. No espírito daquilo que Albert Hirschmann de modo muito perspicaz chamou de "falácia estrutural" - isto é, a estratégia conversacional de penhorar os problemas do varejo do presente para o atacado das utopias que surgiriam depois da virada de mesa estrutural da realidade - Ronai Rocha transforma em pergunta um mote que opera como tabu inquestionável nas rodas de chimarrão dos eventos nas faculdades de educação mas também nos bares próximos aos campi: "educar é um ato político?", pergunta para si mesmo o professor e imediatamente se põe a perseguir a resposta em uma reflexão que parte da admissão do fato de que se é possível ver a fumaça das queixas acerca dos usos ideológicos da sala de aula, a honestidade intelectual impõe o dever de procurar o fogo.

É verdade, pondera Ronai Rocha, que nas faculdades de filosofia não há prensas operando a pleno vapor e imprimindo artigos sobre Marx, marxismo e marxisses. Porém, o autor reflete em uma direção que não cessa de considerar algo como um "marxismo atmosférico". Para penetrar nessa atmosfera, Ronai segura firmemente na mão da recentemente canceladíssima Hannah Arendt. Na companhia da pensadora, o professor esboça e desenvolve algumas posições inegociáveis e que aparecem de diversas formas no texto, chegando a afirmar, por exemplo, que "a educação progressista, tal como foi concebida a partir dos anos 50, ao procurar, com razões, repensar o papel do professor, pode ter contribuído para a erosão da autoridade do professor".

1 Doutorando do programa de pós-graduação em filosofia da Universidade Federal de Santa Maria (PPG-Fil/UFSM). E-mail: costavhr@gmail.com 
A reflexão sobre a tensão entre o imperativo político de constatação da onipresença da política na educação e o imperativo pedagógico de honestidade intelectual da ética profissional leva o professor Ronai a sugerir que procurando bem, encontramos obviedades no coração das nossas perplexidades. Ora, se "tudo é ideologia" como desejam algumas angélicas figuras bem-intencionadas que purgam seus mal-estares sociais em sala da aula, como haveríamos de nos surpreender com o surgimento de formulações como "ideologia de gênero"? As diferenças reais, diz o professor, não desaparecem por decreto. Tendo em Arendt uma companheira de viagem, Ronai observa a insustentável leveza da ideia de atribuir às nossas crianças a responsabilidade pelo futuro. Convictos de que um outro mundo é possível e que deve ser construído, as falanges docentes perpetuam um legítimo "extravio da mística da escola" diante da qual a ideia do Escola sem partido, "mais do que uma proposta, parece um sintoma".

Ronai dedica algumas boas páginas à análise das ideias daquele pensador que se transformou no totem da tribo dos sem-partido: Max Weber. Nos lembrando do contexto histórico no qual a reflexão de Weber é engendrada, Ronai enfatiza a ideia weberiana de realização do "esforço de caráter" que é a abstenção do papel de profeta ou conselheiro espiritual por parte do professor. Observando que já Robert Musil nos alertava para o temperamento despótico dos filósofos que mobilizam suas tropas de ideias para conquistar territórios culturais - e observando também como esse despotismo noético se converteu não raramente em colaboracionismo com autoritarismos políticos - Ronai Rocha adverte: chame-se o professor pela alcunha que se preferir chamar - "educador" ou "trabalhador da educação", como o autor já dissera no livro anterior -, mas ele sempre será um adulto diante de crianças. E é nesse sentido que é uma prerrogativa de honestidade intelectual separar fatos de valores. Por mais que os jovens estejam sempre cheios de entusiasmos para, como observa Weber, receber de presente as "visões de mundo" dos eventuais mestres, esse não é o papel do professor. Pelo contrário, "de todo professor pode ser exigido o reconhecimento que seu trabalho pertence ao campo do conhecimento científico" e isso deve ser uma dimensão de sua "autoconsciência profissional". Curiosamente, atenta Ronai, mesmo Weber seria acusado de "marxismo cultural" pelos sem-partido na medida em que adverte sobre o desencantamento do mundo advindo da compreensão do papel da ciência na história da humanidade.

Atentando para a gravidade de fatos recentes como a conclamação, por parte de secretários de educação, para que professores se comprometam a ensinar a gurizada a ler e contar, Ronai busca as origens desse clima de extravio. Aponta, por exemplo, o modo como a nova sociologia da educação, no início dos anos 70, causou uma espécie de esquizofrenia profissional: o docente passou a viver dentro da escola como se fosse um analista que a vê de fora. Para Ronai Rocha, tudo se passa no universo docente como se o verdadeiro momento de realização vocacional do profissional do ensino não fosse o varejo da sala de aula mas o atacado ideológico das faculdades de educação. E se Quando ninguém educa concluía com essa constatação que impregnará Escola partida de capa a capa, neste último Ronai oferece relatos ainda mais completos desde os quais aparecem as premissas teóricas protocolares desde as quais essa atmosfera se instalou. Ronai observa, por exemplo que, nos anos 70, Demerval Saviani "acreditava piedosamente que o estado da arte marxista era tal que permitia ao teórico da educação ter acesso às leis da sociedade e da história". É a época em que se consolida, conforme visto em Quando ninguém educa, o "populismo pedagógico" que, para "dar voz ao oprimido", deixa falar sozinho quem gostaria de ouvir. Ronai ainda menciona o lançamento, em 1980, de Cuidado, escola!, um livro de ideias fora de lugar no qual "a elite pedagogica 
de um país que apenas começava o esforço da universalização do ensino público adotou, de torma tão entusiasmada quanto descontextualizada, o discurdo da crise escolar da Suíça". Ronai constrói assim o panorama desde o qual a falácia estrutural constitui o nervo da própria visão de mundo, de escola e de sociedade de uma geração que, para não encarar a aspereza do presente, rifou o irrecuperável tempo de gerações inteiras com elucubrações magnãnimas sobre futuros desejáveis.

Se digo que é possível ver uma trilogia na qual Escola partida deve estar junto de Quando ninguém educa e Sentimentos de outono nas prateleiras das livrarias e bibliotecas é porque há mais de vinte anos Ronai Rocha parece convicto de que a mística da escola e do professor realiza "a tarefa mais antiga do mundo: entregar o mundo para uma nova geração da melhor forma que podemos". Nesse cenário, a posse do que há de mais pertinente no universo do ensino e da aprendizagem deve ser capaz de prevenir professores e professoras das tentações do desconstrucionismo, do relativismo e de outros ismos que incidem sociologicamente - isto é, em terceira pessoa - no chão da escola no qual é preciso operar pedagogicamente, em primeira pessoa. As atitudes de relativização do conhecimento não são importantes? Sem dúvida! Mas, como o escorpião da fábula, não podem enfiar seu ferrão na rã da epistemologia da aprendizagem. Em uma direção que atinge falanges docentes de todas as querências, Ronai Rocha observa que se não é mais legítimo fundamentar ética na religião, também não é legítimo fundamentá-la numa crítica da sociedade.

Esse é um gostinho do livro que já teve mesmo uma elipse publicada como excerto no blog da editora Contexto². Penso que Escola partida correrá o mesmo risco que Quando ninguém educa: esbarrar na intransigência dos narcisismos políticos que imobilizam o pensamento e a prática política-e-pedagógica - assim, desesperadoramente misturadas - do país há algum tempo. Ronai Rocha diz coisas que, no Brasil de 2020, podem fomentar discussões capazes de abalar amizades. Eu sei, todo mundo sabe e o professor Ronai também sabe que diante de certas "imagens que nos mantém presos", o pensamento é obrigado ao trabalho de Hércules, ou de Sísifo, de pular sobre a própria sombra. E se o rompimento com elementos tão primários das imagens que temos de nós mesmos pode ser dolorosa e traumática, talvez seja o caso de preparar o pulo desde a comedida subida de uma escada. Escola partida é mais um degrau que o professor Ronai oferece para essa escada que, no espírito de Wittgeinstein, espero que possa ser um dia deixada para trás.

\section{REFERÊNCIAS}

ROCHA, Ronai. Escola partida: ética e política em sala de aula. Editora Contexto, 2020.

2 Esse texto pode ser encontrado aqui: https://bit.ly/35L3VZx 